Louisiana State University

LSU Digital Commons

$1-1-1996$

\title{
Carbohydrate mobilization during germination of post-diapausing gemmules of the freshwater sponge Eunapius fragilis
}

\author{
Stephen H. Loomis \\ Connecticut College \\ Louis F. Ungemach \\ Connecticut College \\ Bruce R. Branchini \\ Connecticut College \\ Steven C. Hand \\ University of Colorado Boulder \\ Paul E. Fell \\ Connecticut College
}

Follow this and additional works at: https://digitalcommons.Isu.edu/biosci_pubs

\section{Recommended Citation}

Loomis, S., Ungemach, L., Branchini, B., Hand, S., \& Fell, P. (1996). Carbohydrate mobilization during germination of post-diapausing gemmules of the freshwater sponge Eunapius fragilis. Biological Bulletin, 191 (3), 393-401. https://doi.org/10.2307/1543012 


\title{
Carbohydrate Mobilization During Germination of Post-Diapausing Gemmules of the Freshwater Sponge Eunapius fragilis
}

\author{
STEPHEN H. LOOMIS ${ }^{1}$, LOUIS F. UNGEMACH ${ }^{1}$, BRUCE R. BRANCHINI ${ }^{2}$, \\ STEVEN C. HAND ${ }^{3}$, AND PAUL E. FELL ${ }^{1}$ \\ ${ }^{1}$ Department of Zoology, ${ }^{2}$ Department of Chemistry, Connecticut College, New London, Connecticut \\ 06320; and ${ }^{3}$ Department of EPO Biology, University of Colorado, Boulder, Colorado 80309-0334
}

\begin{abstract}
Post-diapausing gemmules of the freshwater sponge Eunapius fragilis were found to contain sorbitol and glycogen as their primary carbohydrates. The sorbitol probably acts to increase the tolerance of the gemmules to freezing and desiccation. During germination, average sorbitol levels-measured as micromoles of sorbitol per gram of fresh weight of gemmule tissue ( $\mu \mathrm{mol} /$ gfw)-declined from a control value of $36 \mu \mathrm{mol} / \mathrm{gfw}$ to about $4 \mu \mathrm{mol} / \mathrm{gfw}$. Concomitantly, average glycogen levels increased from a control value of $29 \mu \mathrm{mol} / \mathrm{gfw}$ to a steady-state level of $62 \mu \mathrm{mol} / \mathrm{gfw}$. It is probable that glycogen is being synthesized at the expense of sorbitol. The breakdown of sorbitol was associated with an increase in the activity of sorbitol dehydrogenase from undetectable levels in dormant gemmules to a maximum of $0.2 \mu \mathrm{mol} /$ $\min \cdot \mathrm{mg}$ protein after $30 \mathrm{~h}$ of exposure to $20^{\circ} \mathrm{C}$. Aldose reductase activity remained constant throughout germination. These data support the hypothesis that the decrease in sorbitol levels is the result of an increase in the rate of catabolism by sorbitol dehydrogenase. The total activity of glycogen synthase did not change during germination; however, the activity of glucose-6-phosphatedependent glycogen synthase was about 18 times greater than the activity of glucose-6-phosphate-independent glycogen synthase. Total glycogen phosphorylase activity increased from about $1.6 \mathrm{nmol} / \mathrm{min} \cdot \mathrm{mg}$ protein to $3.6 \mathrm{nmol} / \mathrm{min} \cdot \mathrm{mg}$ protein during germination. At the same time, however, the percentage of glycogen phosphorylase $a$ decreased from almost $100 \%$ to about $84 \%$.
\end{abstract}

Received 10 October 1995; accepted 27 September 1996.
This decrease would attenuate the apparent increase in activity. cAMP levels remained constant throughout germination. The observed changes in the level of glycogen in the gemmules are not simply due to changes in the activity of either glycogen phosphorylase or glycogen synthase.

\section{Introduction}

The life cycle of many freshwater sponges includes the formation of structures called gemmules. These consist of a mass of undifferentiated cells enclosed by a collagenous capsule. Gemmules are resistant to many environmental perturbations and are often produced as the sponge enters a period of environmental stress. For example, in southern New England the freshwater sponge Eunapius fragilis over-winters in the form of gemmules. After the sponge produces gemmules in the early fall, the adult tissue dies, leaving the gemmules attached to the substratum. In spring, the gemmules germinate to form the adult sponge again (Fell, 1987). In contrast, in temporary swamps in the southeastern United States the same species produces gemmules as the swamp dries in the summer. In this case the gemmules are exposed to hot, dry conditions and germinate when the swamps form again (Poirrier, 1969).

The physiological state of the gemmules from Eunapius changes with time and can be divided into three distinct stages: (1) diapause, (2) quiescence, and (3) germination (Fell, 1987). As gemmules are formed by Eunapius fragilis, they are initially in diapause, a state of dormancy controlled by some as yet unknown endoge- 
nous factor or factors. In this state, the gemmules will not germinate even if exposed to favorable conditions. For example, gemmules that are collected in New England just after formation will not germinate when they are warmed to $20^{\circ} \mathrm{C}$, even if kept at that temperature for up to 4 months. Quiescence occurs in gemmules collected at least 3 to 4 months after formation. In this case, the metabolism and development of gemmules is simply being depressed by low temperature, and they will readily germinate when warmed to $20^{\circ} \mathrm{C}$. Similarly, in the laboratory, diapause can be broken by exposing the gemmules to cold $\left(5^{\circ} \mathrm{C}\right)$ for 4 to 5 months or by exposing them to $5^{\circ} \mathrm{C}$ for 4 to 6 weeks followed by desiccation for 7 days (Fell, 1987). The breaking of diapause represents a basic shift from endogenous control of dormancy to environmental control of quiescence.

Germination of gemmules represents the period of development leading from post-diapause quiescence to the differentiated adult sponge. In Eunapius, emergence of the adult sponge tissue from the gemmule occurs 42 to $50 \mathrm{~h}$ after exposure to $20^{\circ} \mathrm{C}$. Very little is known of the biochemical changes that occur during germination. Almost all of the information about these changes is based on nonquantitative histochemical methods and is limited to compounds easily stained in thin section (Simpson, 1984). The purpose of this paper, therefore, is to identify the major carbohydrates present in the post-diapausing gemmules of Eunapius fragilis and to examine changes in the levels of these compounds during germination.

\section{Materials and Methods}

\section{Gemmules}

Gemmules used for the measurement of possible energy sources during germination were collected from Gallop Pond in North Stonington, Connecticut, in late October of 1991. Gemmules used in the enzyme studies were collected from Stony Brook in South Hadley, Massachusetts, during early February of 1992. All gemmules were kept at $5^{\circ} \mathrm{C}$ until June to ensure that diapause was broken.

\section{Germination experiments}

Samples of gemmules ranging in size from 100 to $300 \mathrm{mg}$ wet weight were placed in individual test tubes containing $10 \mathrm{ml}$ of filtered stream water at $5^{\circ} \mathrm{C}$. At the initiation of the experiment, the cold stream water was decanted from all of the gemmule samples and was replaced by filtered stream water at $20^{\circ} \mathrm{C}$. All samples were well aerated and maintained at $20^{\circ}-23^{\circ} \mathrm{C}$. Periodically, the stream water was decanted from three of the gem- mule samples, which were then homogenized according to the protocol for the particular experiment (as outlined below).

\section{Extraction of carbohydrates}

Glycogen. Glycogen was extracted from the gemmules with cold $80 \%$ ethanol. Gemmules $(300 \mathrm{mg})$ were ground under liquid nitrogen in a mortar and pestle. The powder was transferred to $50-\mathrm{ml}$ centrifuge tubes and the liquid nitrogen was allowed to evaporate. Five milliliters of $80 \%$ ethanol was added to the centrifuge tubes containing the powdered gemmules and was mixed thoroughly on a vortex mixer. The ethanol solution was placed at $4^{\circ} \mathrm{C}$ overnight to allow all of the glycogen to precipitate and was then centrifuged at $10,000 \times g$ for $20 \mathrm{~min}$. The supernatant was retained for ethanol-soluble carbohydrate measurement and the pellet was washed twice more with $2 \mathrm{ml}$ of cold $80 \%$ ethanol. The washings were combined with the original supernatant. The final pellet was dissolved in $5 \mathrm{ml}$ of $30 \% \mathrm{KOH}$ and heated to $100^{\circ} \mathrm{C}$ in a boiling water bath. After the sample was cooled to room temperature, $7.5 \mathrm{ml}$ of $80 \%$ ethanol was added, and the glycogen was precipitated at $4^{\circ} \mathrm{C}$ overnight. Glycogen was collected by centrifuging the sample at $10,000 \times g$ for $20 \mathrm{~min}$ and the resulting pellet was washed twice more with cold $80 \%$ ethanol. The pellet was dried under nitrogen, then dissolved in $5 \mathrm{ml}$ distilled water; the amount of glycogen in the solution was measured using the anthrone method of Umbreit et al. (1972). The amount of glycogen measured using this method was not significantly different from that measured by the amyloglucosidase-based assay.

\section{Identification of ethanol-soluble carbohydrates}

High-performance liquid chromatography (HPLC). The combined supernatant from the ethanol extraction was dried under nitrogen, redissolved in either $\mathrm{H}_{2} \mathrm{O}$ (for HPLC) or $\mathrm{D}_{2} \mathrm{O}$ (for NMR) and filtered through a 0.45 $\mu \mathrm{m}$ filter prior to further analysis. Initial identification of carbohydrates in these samples was determined by HPLC using a Waters Radial-Pak silica cartridge modified with tetraethylenepentamine according to the methods of Hendrix et al. (1981). Carbohydrates were detected using an LDC/Milton Roy RefractoMonitor III.

Nuclear magnetic resonance (NMR). The ethanol-soluble carbohydrates were further characterized by ${ }^{1} \mathrm{H}$ and ${ }^{13} \mathrm{C}$-NMR on a Bruker AC250 NMR. ${ }^{1} \mathrm{H}$ - and ${ }^{13} \mathrm{C}$ NMR spectra were measured at 250.1 and $62.9 \mathrm{MHz}$ and chemical shift values are reported relative to the internal standard, sodium, 2,2-dimethyl-2-silapentane-5sulfonate (DSS).

Sorbitol. Sorbitol in the ethanol-soluble fraction was 
measured enzymatically using the method of Bergmeyer et al. (1974). The incubation solution contained 1 unit of sorbitol dehydrogenase and $1.2 \mathrm{~m} M \mathrm{NADH}$ in $200 \mathrm{~m} M$ sodium phosphate buffer, $\mathrm{pH} 9.5$, in a total volume of $2.0 \mathrm{ml}$. The amount of sorbitol was measured by incubating aliquots $(50 \mu \mathrm{l})$ of standards and samples in the incubation medium for $30 \mathrm{~min}$ and measuring the change in absorbance at $340 \mathrm{~nm}$.

\section{Enzyme assays}

Sorbitol dehydrogenase. Sorbitol dehydrogenase activity was measured at $25^{\circ} \mathrm{C}$ in extracts of gemmules according to a modification of the method of Wolff (1955). Gemmules $(100 \mathrm{mg})$ were homogenized in a Tenbroek homogenizer in $300 \mu$ of grinding buffer ( $20 \mathrm{mM}$ Tris$\mathrm{HCl}, \mathrm{pH}$ 7.32). The homogenate was centrifuged at $10,000 \times g$ for $10 \mathrm{~min}$ and an aliquot $(100 \mu \mathrm{l})$ of the supernatant was placed in $1.7 \mathrm{ml}$ of assay buffer, resulting in a final concentration of $300 \mu M$ NAD in $100 \mathrm{~m} M$ Tris- $\mathrm{HCl}, \mathrm{pH} 9.0$. A baseline rate was recorded, and the assay was then initiated by the addition of $200 \mu \mathrm{l}$ of $1.5 M$ sorbitol (150 $\mathrm{m} M$ final concentration). Activity was followed by measuring the rate of change in the absorbance at $340 \mathrm{~nm}$.

Aldose reductase. Aldose reductase activity in extracts of gemmules was measured at $25^{\circ} \mathrm{C}$ using a modification of the method of Velle (1975). Gemmules were homogenized as described in the methods for sorbitol dehydrogenase and an aliquot $(100 \mu \mathrm{l})$ of the protein solution was placed in $1.6 \mathrm{ml}$ of an assay buffer, resulting in a final concentration of $330 \mu M$ NADPH in $300 \mathrm{~m} M$ Tris- $\mathrm{HCl}$, $\mathrm{pH}$ 7.5. A baseline rate was recorded, and the assay was initiated by the addition of $300 \mu \mathrm{l}$ of $100 \mathrm{~m} M$ glyceraldehyde $(45 \mathrm{~m} M)$. Activity was followed by measuring the rate of change in the absorbance at $340 \mathrm{~nm}$. Aldose reductase has a broad substrate specificity and will catalyze the reduction of a number of aldoses (Hayman and $\mathrm{Ki}$ noshita, 1965). Glyceraldehyde (which results in the synthesis of glycerol) was used as a substrate in these assays instead of glucose (which results in the synthesis of sorbitol) to obtain increased sensitivity (Hayman and $\mathrm{Ki}$ noshita, 1965).

Glycogen synthase. Glycogen synthase activity was measured at $25^{\circ} \mathrm{C}$ in extracts of gemmules according to a modification of the methods of Mendicino et al. (1975). Gemmules $(300 \mathrm{mg}$ ) were homogenized in $0.9 \mathrm{ml}$ of $50 \mathrm{~m} M$ Tris- $\mathrm{HCl}, \mathrm{pH} 7.5$, containing $0.3 \mathrm{M}$ sucrose, $20 \mathrm{~m} M 2$-mercaptoethanol, and $5 \mathrm{~m} M$ EDTA. The homogenate was centrifuged at $10,000 \times g$ for $10 \mathrm{~min}$ and an aliquot $(100 \mu \mathrm{l})$ of the supernatant was added to $0.21 \mathrm{ml}$ of an assay buffer, resulting in a final concentration of $117 \mathrm{~m} M$ Tris- $\mathrm{HCl}, \mathrm{pH} 7.5,29 \mathrm{mM}$ cysteine, and
$100 \mathrm{mg} / \mathrm{ml}$ of glycogen. Glucose-6-phosphate-dependent activity was measured by the addition of glucose-6phosphate to the assay solution to a final concentration of $11.8 \mathrm{mM}$. The assay was initiated by the addition of UDP- $\left[{ }^{14} \mathrm{C}\right]$-glucose to a final concentration of $4.3 \mathrm{mM}$ (specific radioactivity of $50,000 \mathrm{cpm} / \mu$ mole). The assay was terminated after $30 \mathrm{~min}$ by the addition of $1 \mathrm{ml}$ of $10 \%$ trichloroacetic acid. The resulting solution was centrifuged at $10,000 \times g$ for $10 \mathrm{~min}$. The supernatant was removed and added to $4 \mathrm{ml}$ of $95 \%$ ethanol $\left(-20^{\circ} \mathrm{C}\right)$ to precipitate the glycogen. The glycogen was pelleted by centrifuging at $10,000 \times g$ for $10 \mathrm{~min}$. The supernatant was discarded and the glycogen pellet was dissolved in $1 \mathrm{ml}$ distilled water. The glycogen was reprecipitated twice more by adding $4 \mathrm{ml}$ of $95 \%$ ethanol $\left(-20^{\circ} \mathrm{C}\right)$ to this solution, followed by centrifugation. The amount of ${ }^{14} \mathrm{C}$ incorporated into the glycogen from UDPG during the incubation period was measured in a liquid scintillation counter.

Glycogen phosphorylase. Glycogen phosphorylase activity was measured at $25^{\circ} \mathrm{C}$ in extracts from gemmules according to a modification of the method of Mendicino et al. (1975). Gemmules (100 mg) were homogenized in $300 \mu$ l of $50 \mathrm{mM}$ imidazole buffer (pH 7.0), containing $10 \mathrm{~m} M$ magnesium chloride, $2 \mathrm{~m} M$ EDTA, $0.01 \%$ bovine serum albumin, and $1 \%$ glycogen. The solution was centrifuged at $10,000 \times g$ for $10 \mathrm{~min}$ and the supernatant was retained for the assay. Total activity was measured in $1 \mathrm{ml}$ of $50 \mathrm{~m} M$ imidazole, $\mathrm{pH} \mathrm{7.0,} \mathrm{containing} 10 \mathrm{mM}$ magnesium chloride, $2 \mathrm{~m} M$ EDTA, $0.01 \%$ bovine serum albumin, $1.1 \%$ glycogen, $70 \mathrm{~m} M$ potassium phosphate, $300 \mu M$ NADP, $10 \mu M$ glucose-1,6-diphosphate, $4 \mathrm{mM}$ AMP, 1 unit phosphoglucomutase, and 1 unit glucose6-phosphate dehydrogenase. When phosphorylase $b$ was measured, the AMP was omitted. The assay was initiated by the addition of $100 \mu$ l of the protein solution. Activity was determined by measuring the rate of change in the absorbance at $340 \mathrm{~nm}$. Protein concentration in extracts used for all enzyme assays was determined according to the methods of Peterson (1977).

cAMP assay. Adenosine $3^{\prime}, 5^{\prime}$ cyclic monophosphate (cAMP) in extracts from gemmules of Eunapius fragilis was measured using an ${ }^{125}$ I radioimmunoassay according to the methods outlined in the Rianen (Dupont Medical Products) Assay System. Samples were prepared by homogenizing $30 \mathrm{mg}$ of gemmules in $0.5 \mathrm{ml}$ of cold $\left(4^{\circ} \mathrm{C}\right) 6 \%$ trichloroacetic acid. cAMP recovery during extraction was determined by adding about $0.1 \mathrm{pmol}$ $(4,000 \mathrm{CPM})$ of ${ }^{3} \mathrm{H}$ cAMP to the homogenate as an internal standard. The extracts were centrifuged at $2500 \times$ $g$ for $15 \mathrm{~min}$, and the supernatant was extracted four times with $2.5 \mathrm{ml}$ of water-saturated ether. The aqueous layers were then dried under a stream of air at $70^{\circ} \mathrm{C}$. The 
resulting residue was dissolved in $0.5 \mathrm{ml}$ of the radioimmunoassay assay buffer, and cAMP concentrations were measured in 100- $\mu$ l aliquots of this solution.

Statistical analysis. Statistical differences among treatments were assessed by analysis of variance. Values are expressed as means $\pm 1 \mathrm{SE}$.

\section{Results}

\section{Ethanol-soluble carbohydrates}

HPLC analysis of the ethanol-soluble fraction showed a single peak that co-eluted with sorbitol and remained single when spiked with authentic sorbitol (data not shown). Because it is difficult to exclude the presence of other six-carbon polyols solely on the retention times on the HPLC column, we used ${ }^{1} \mathrm{H}$ - and ${ }^{13} \mathrm{C}-\mathrm{NMR}$, which together can distinguish the isomeric hexitols, to further analyze the ethanol-soluble fraction. The spectra for both ${ }^{1} \mathrm{H}$ - and ${ }^{13} \mathrm{C}$-NMR were virtually identical to the spectra, obtained under identical acquisition conditions, for authentic sorbitol (Fig. 1). The chemical shifts for ${ }^{13} \mathrm{C}$-NMR are shown in Table I. Further, there were no additional peaks in the spectra, eliminating the possibility of other compounds being present. Based on the HPLC and NMR data, it is clear that sorbitol comprises the major ethanol-soluble carbohydrate in post-diapause gemmules.

Sorbitol levels determined by sorbitol dehydrogenase and expressed as micromoles per gram of fresh gemmule tissue $(\mu \mathrm{mol} / \mathrm{gfw})$ declined rapidly in germinating gem-
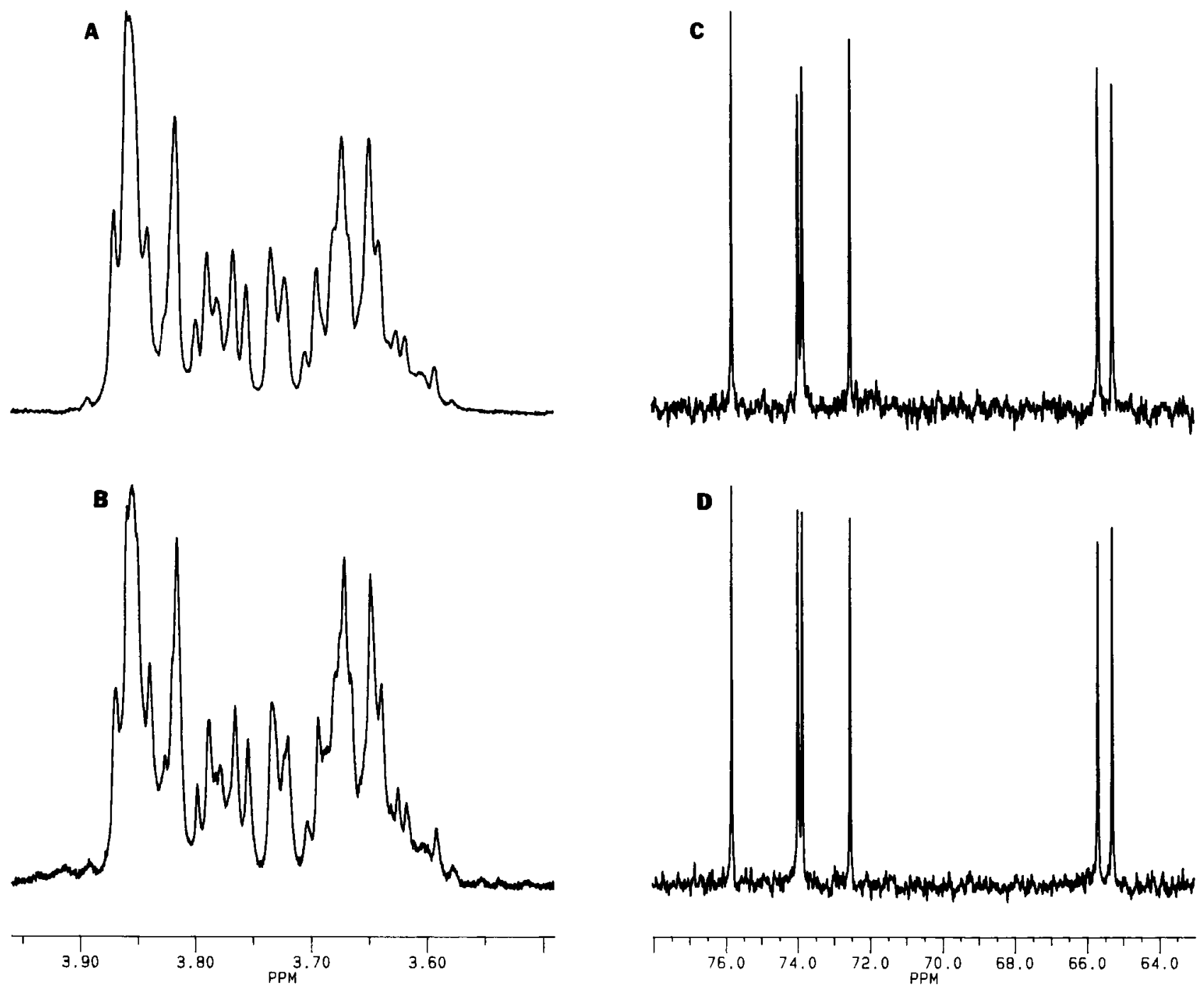

Figure 1. ${ }^{1} \mathrm{H}-\mathrm{NMR}$ spectra of authentic sorbitol (A) and the cthanol-soluble fraction of Eunapius fragilis gemmules (B) and ${ }^{13} \mathrm{C}-\mathrm{NMR}$ spectra of authentic sorbitol $(\mathrm{C})$ and the ethanol-soluble fraction of $E u$ napius fragilis gemmules $(\mathrm{D})$. 
Table I

${ }^{13} \mathrm{C}$-NMR chemical shifts measured downfield from the internal standard DSS in $\mathrm{D}_{2} \mathrm{O}$ of authentic sorbitol and the ethanol soluble fraction from gemmules of Eunapius fragilis

\begin{tabular}{lllllll}
\hline \multicolumn{1}{c}{ Sample } & \multicolumn{5}{c}{${ }^{13}$ C chemical shifts } \\
\hline E. fragilis extract & 65.3 & 65.7 & 72.5 & 73.8 & 74.0 & 75.8 \\
Sorbitol & 65.2 & 65.7 & 72.5 & 73.8 & 73.9 & 75.8 \\
\hline
\end{tabular}

mules-from a maximum of about $36 \mu \mathrm{mol} / \mathrm{gfw}$ to a steady-state level of about $4 \mu \mathrm{mol} / \mathrm{gfw}$ by $36 \mathrm{~h}$ (Fig. 2). Sorbitol remained constant over the same time in gemmules maintained at $5^{\circ} \mathrm{C}$. Concomitant with the decline in sorbitol, there was a significant increase in glycogen content measured by anthrone-from about $29 \mu \mathrm{mol}$ hexose equivalents/gfw to about $62 \mu \mathrm{mol}$ hexose equivalents/gfw (Fig. 3). As with the sorbitol, glycogen levels remained constant when gemmules were maintained at $5^{\circ} \mathrm{C}$.

\section{Enzyme activities}

Sorbitol dehydrogenase activity was undetectable in the quiescent gemmules. During gemmule germination at $20^{\circ} \mathrm{C}$, activity increased dramatically to a maximum of $0.2 \mu \mathrm{mol} / \mathrm{min} \cdot \mathrm{mg}$ protein at $36 \mathrm{~h}$ (Fig. 4). Between 36 and $48 \mathrm{~h}$, the activity declined again, to about $0.05 \mu \mathrm{mol} / \mathrm{min} \cdot \mathrm{mg}$ protein. In contrast, the activity of aldose reductase remained at about $8 \mu \mathrm{mol} / \mathrm{min} \cdot \mathrm{mg}$ protein throughout germination (Fig. 4).
Total glycogen phosphorylase activity increased by a factor of 2.3 during germination-from a low of 1.6 to a high of $3.7 \mathrm{nmol} / \mathrm{min} \cdot \mathrm{mg}$ protein (Fig. 5). Maximal activity occurred by $42 \mathrm{~h}$. The percentage of glycogen phosphorylase $a$ declined from a maximum of $100 \%$ in quiescent gemmules to a minimum of $84 \%$ at $42 \mathrm{~h}$. In contrast to changes in glycogen phosphorylase activity, there were no significant changes in the activity of either the glucose-6-phosphate-dependent or the glucose-6phosphate-independent glycogen synthase during germination (Fig. 6). The activity of the glucose-6-phosphatedependent glycogen synthase is 18 times greater than the activity of the glucose-6-phosphate-independent glycogen synthase. Note, however, that the total glycogen phosphorylase activity is three times higher than the glucose-6-phosphate-independent glycogen synthase activity and one-fourth of the activity of the glucose-6-phosphate-dependent glycogen synthase activity.

cAMP concentrations did not change significantly during the germination of gemmules of Eunapius fragilis, ranging from $3.6 \pm 0.7$ to $4.0 \pm 0.8 \mathrm{pmol} / \mathrm{mg}$ protein.

\section{Discussion}

Germination of Eunapius fragilis gemmules under the conditions described here occurs during the first 42 to $50 \mathrm{~h}$ following exposure to $20^{\circ}-23^{\circ} \mathrm{C}$. During that time, sorbitol levels decline dramatically and glycogen levels increase. It is possible that the sorbitol is being used to synthesize glycogen. Indeed, the changes in the two carbohydrates-measured as micromoles per gram of fresh

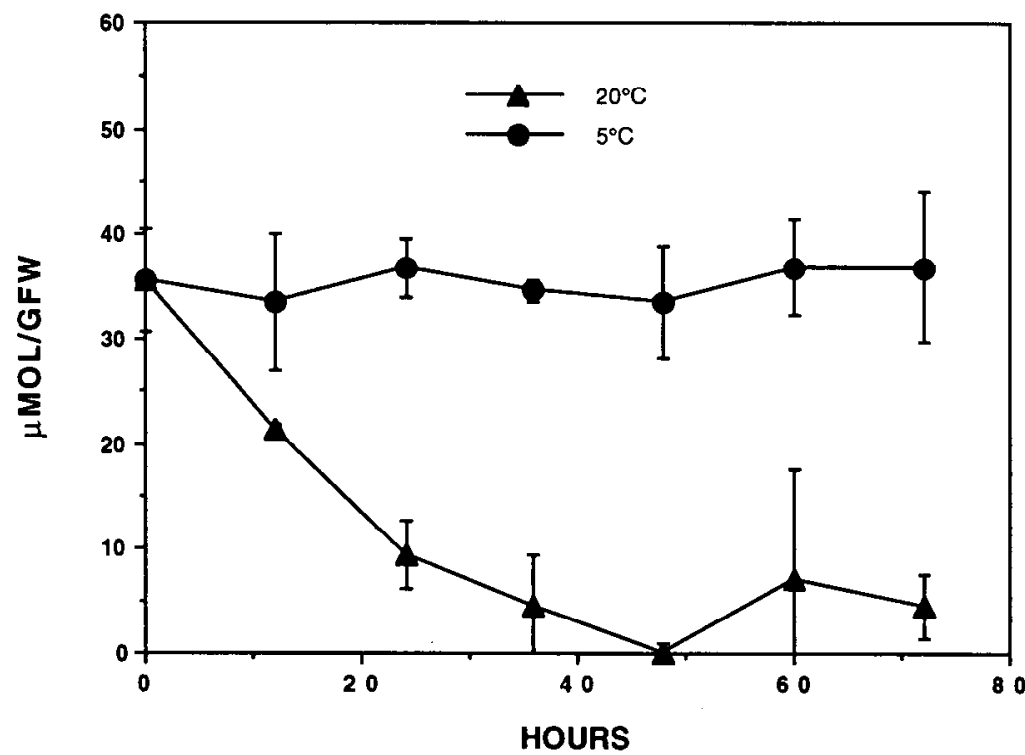

Figure 2. Changes in the levels of sorbitol in gemmules of Eunapius fragilis during germination. Values are expressed as means $\pm 1 \mathrm{SE}(n=3)$. 


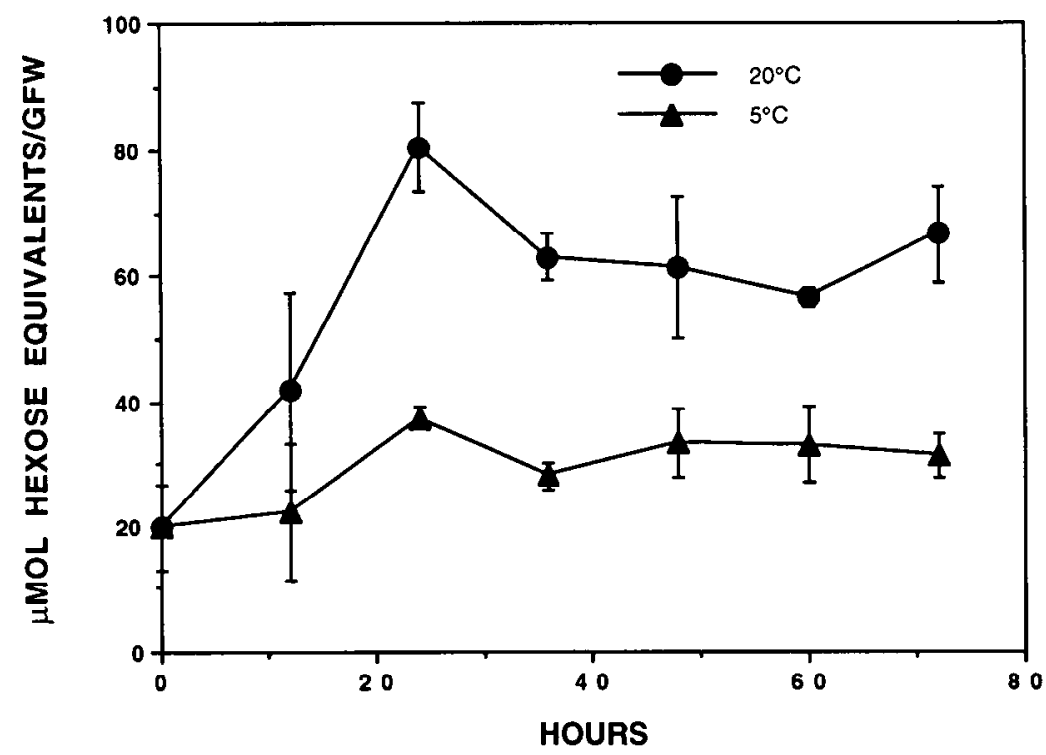

Figure 3. Changes in the levels of glycogen in gemmules of Eunapius fragilis during germination. Values are expressed as means $\pm 1 \mathrm{SE}(n=3)$.

weight of gemmule tissue ( $\mu \mathrm{mol} / \mathrm{gfw})$-balance one another very closely: sorbitol decreases by $32 \mu \mathrm{mol} / \mathrm{gfw}$ (from an average control value of $36 \mu \mathrm{mol} / \mathrm{gfw}$ to an average steady-state level of $4 \mu \mathrm{mol} / \mathrm{gfw}$ ), and glycogen increases by $33 \mu \mathrm{mol} / \mathrm{gfw}$ (from an average control value of $29 \mu \mathrm{gfw}$ to an average steady-state value of $62 \mu \mathrm{mol} /$ $\mathrm{gfw})$. The synthesis of glycogen from a carbohydratc prccursor is consistent with observations for other develop- ing invertebrates; for example, during the first few hours of germination, the osmotic pressure of gemmules of Spongilla lacustris drops precipitously (Rasmont, 1975). Rasmont (1975) attributed this reduction in osmotic pressure to the resynthesis of glycogen from an unidentified low molecular weight precursor. Also, in insect larvac, the synthesis of glycerol and sorbitol during exposure to cold occurs at the expense of glycogen, and

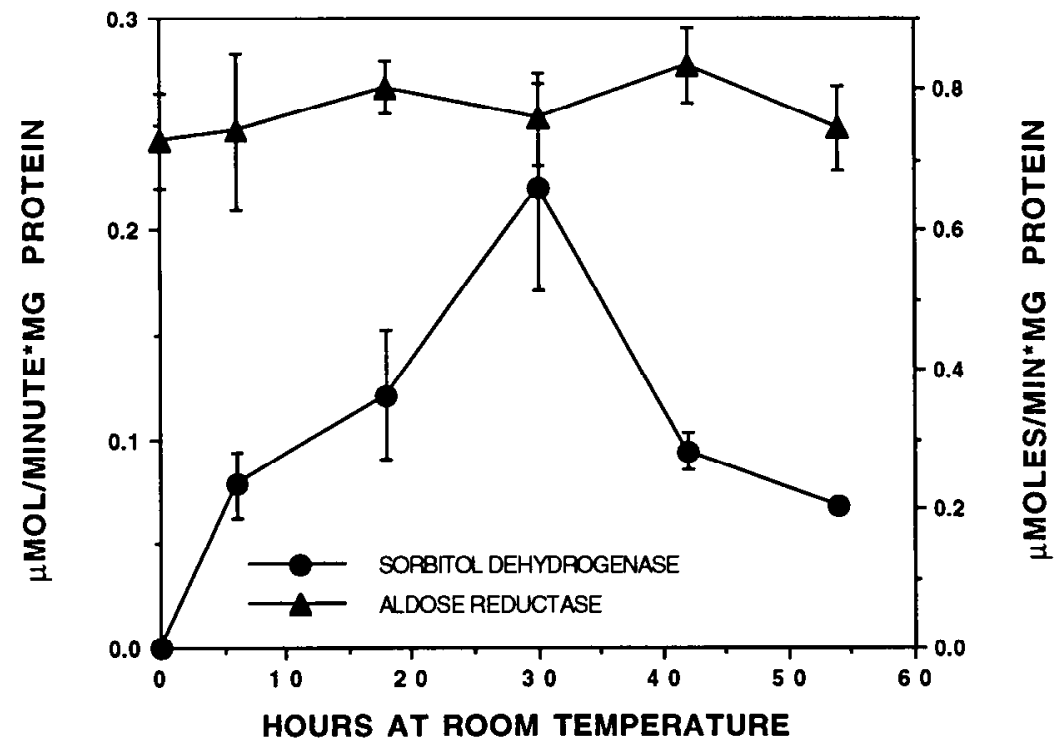

Figure 4. Changes in the activity of sorbitol dehydrogenase and aldose reductase in gemmules of $E u$ napius fragilis during germination. Assay conditions are as outlined in the Materials and Methods section. Values are expressed as means $\pm 1 \mathrm{SE}(n=3)$. 


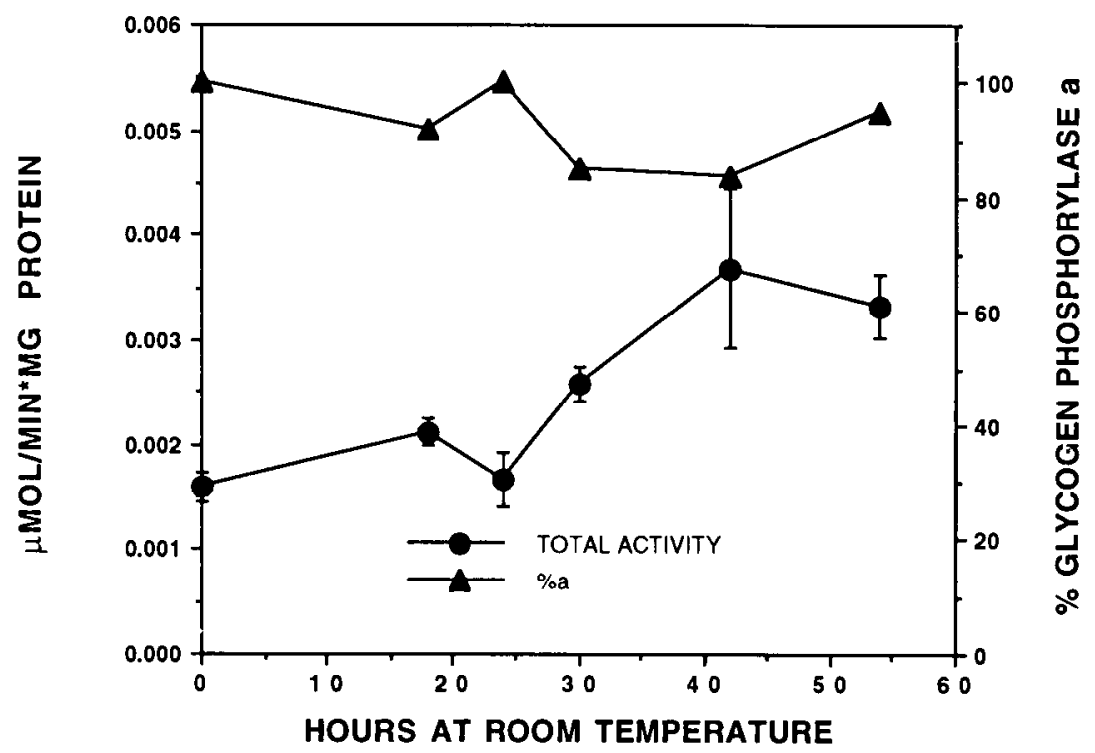

Figure 5. Changes in the activity of total glycogen phosphorylase and the percentage of glycogen phosphorylase $a$ in gemmules of Eunapius fragilis during germination. Assay conditions are as outlined in the Materials and Methods section. Values are expressed as means $\pm 1 \mathrm{SE}(n=3)$.

during subsequent warming, glycogen levels are subsequently restored at the expense of sorbitol (Storey and Storey, 1983). Clegg (1964) reports that during the preemergence development of Artemia salina cysts, trehalose is utilized to synthesize glycogen and glycerol during development. In this case, the decrease in trehalose can account for all of the synthesis of glycogen and glycerol plus the oxygen consumption measured during pre- emergence (Clegg, 1964). This is not the case for Eunapius fragilis, however. The amount of sorbitol breakdown can just account for the amount of glycogen synthesized. Calorimetric measurement of heat dissipation of the gemmules of Eunapius fragilis shows that the energy flow of gemmules increases dramatically during germination (Loomis et al., 1996). Clearly, another source of energy must be available during germination. This

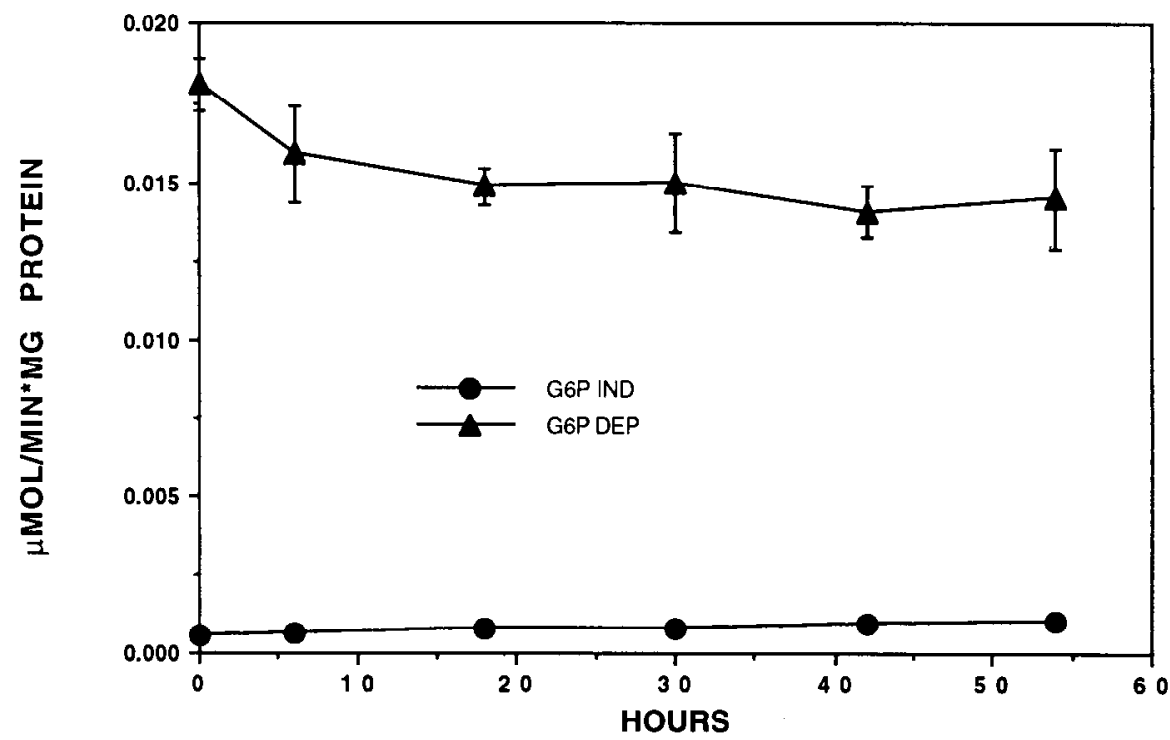

Figure 6. Changes in the activity of glucose-6-phosphate-dependent and glucose-6-phosphate-independent glycogen synthase in gemmules of Eunapius frayilis during germination. Assay conditions are as outlined in the Materials and Methods section. Values are expressed as means $\pm 1 \operatorname{SE}(n=3)$. 
source of energy is most probably nutrients contained in yolk platelets. The thesocytes of gemmules are packed with yolk platelets, and these platelets begin to shrink about $24 \mathrm{~h}$ after the initiation of germination in Spongilla lacustris (Simpson, 1984).

Using histological techniques, De Vos (1977) has shown that glycogen is present in the early stages of gemmule formation and later disappears. This is consistent with the lower levels of glycogen measured in post-diapausing gemmules of Eunapius fragilis. It may be that the glycogen originally present is used to synthesize sorbitol during development of gemmules, although this has yet to be determined.

Sorbitol is a well-known cryoprotectant produced during the winter in insects (see Lee, 1989; Baust et al., 1985, for reviews), and it probably imparts increased freezing and desiccation tolerance to gemmules of Eunapius fragilis. In fact, gemmules of Eunapius fragilis are remarkably tolerant to freezing and desiccation (Fell, 1990; Boutselis et al., 1990). For example, post-diapausing, fully hydrated gemmules will germinate following a 30 day exposure to $-72^{\circ} \mathrm{C}$ (Boutselis et al., 1990), and they survive air-drying for several weeks (Fell, 1990). Increased tolerance to cold and desiccation is no doubt important for the survival of Eunapius fragilis since this species is found in environments that can dry in the summer (such as swamps in the southeastern United States) and freeze in the winter (such as ponds and streams in the northeastern United States).

To begin to understand the biochemical mechanisms controlling the breakdown of sorbitol and the synthesis of glycogen during germination in Eunapius fragilis gemmules, we measured the activities of the proximate enzymes responsible for catabolism and anabolism of each of these compounds. Of course such analyses do not rule out modulations in other auxiliary enzymes that may also contribute to the altered mobilization of carbohydrate stores.

Sorbitol breakdown may result from an increase in the activity of sorbitol dehydrogenase (the catabolic enzyme), a decrease in the activity of aldose reductase (the anabolic enzyme), or both. In Eunapius, sorbitol breakdown during the germination of gemmules appears to be the result of an increase in the activity of sorbitol dehydrogenase. The activity of this enzyme increases from undetectable levels in quiescent gemmules to more than $0.2 \mu \mathrm{mol} / \mathrm{min} \cdot \mathrm{mg}$ protein during the first $30 \mathrm{~h}$ of germination; during the same period, more than $95 \%$ of the sorbitol breakdown occurs. Aldose reductase activity remains unchanged throughout germination. Therefore, increased catabolic capacity could account for the observed changes in sorbitol levels during germination. The increase in maximal activity of the catabolic enzyme, sorbitol dehydrogenase, could be the result of either de novo synthesis of the enzyme or catalytic activation via covalent modification during the early stages of germination; it is still unclear whether one or both of these processes are responsible.

Similarly, glycogen synthesis could result from an increase in the activity of glycogen synthase (the anabolic enzyme), a decrease in the activity of glycogen phosphorylase (the catabolic enzyme), or both. In Eunapius, there is no clear indication whether any of these possibilities occur. Glycogen synthase activity, whether dependent on or independent of glucose-6-phosphate, remains unchanged during germination. Total glycogen phosphorylase activity, on the other hand, increases during germination, but this increase is at least partly nullified by the conversion of some of the active glycogen phosphorylase $a$ form to its inactive $b$ form. Similarly, there are no changes in the concentration of cAMP (this paper), ATP or AMP (Loomis et al., 1996) that could promote allosteric or covalent changes in vivo in glycogen phosphorylase and glycogen synthase. Indeed, the relatively high concentrations of cAMP may keep most of the glycogen synthase in the glucose-6-phosphate-dependent form. These data are in contrast with results from Spongilla lacustris gemmules in which cAMP levels are dramatically reduced during the first $2 \mathrm{~h}$ of exposure to $20^{\circ} \mathrm{C}$ (Simpson and Rodan, 1976). Simpson (1984) has suggested that the reduction is due to the combination of a decrease in adenylate cyclase activity and an increase in cAMP phosphodiesterase activity. In Spongilla, the low levels of cAMP could result in a decrease in the breakdown of glycogen through the inhibition of glycogen phosphorylase.

Clearly, other control mechanisms that do not involve changes in cAMP must be responsible for the synthesis of glycogen in gemmules of Eunapius fragilis. It is possible that changes in the concentration of glucose-6-phosphate during germination could increase the rate of glycogen synthesis by allosterically activating the glucose-6phosphate-dependent glycogen synthase. We are examining this possibility.

\section{Acknowledgments}

This work was supported by NSF grants DCB9018579 and IBN 9306652 to SCH.

\section{Literature Cited}

Baust, J. G., R. R. Rojas, and M. D. Hamilton. 1985. Life at low temperatures: representative insect adaptations. Cryo. Lett. 6: 199-210.

Bergmeyer, H. U., W. Gruber, and I. Gutman. 1974. D-Sorbitol. Pp. 1323-1326 in Methods in Enzymatic Analysis. H. U. Bergmeyer, ed. Academic Press, New York.

Boutselis, N. J., P. E. Fell, and S. H. Loomis. 1990. Low tempera- 
ture tolerance of the gemmules of Eunapius fragilis. J. Exp. Zool. 255: $125-129$.

Clegg, J.S. 1964. The control of emergence and metabolism by external osmotic pressure and the role of free glycerol in developing cysts of Artemia salina. J. Exp. Biol. 41: 879-892.

De Vos, L. 1977. Morphogenesis of the collagenous shell of the gemmules of a fresh-water sponge Ephydatia fluviatilis. Arch. Biol. 88: 479-494.

Fell, P. E. 1987. Synergy between low temperature and desiccation in breaking gemmule diapause of Eunapius fragilis (Leidy). Int. J. Invertebr. Reprod. Dev. 12: 331-340.

Fell, P. E. 1990. Environmental factors affecting dormancy in the freshwater sponge Eunapius fragilis (Leidy). Invertebr. Reprod. Dev. 18: 213-219.

Hayman, S., and J. H. Kinoshita. 1965. Isolation and properties of lens aldose reductase. J. Biol. Chem. 240: 877-882.

Hendrix, D. L., R. E. Lee, J. G. Baust, and H. James. 1981. Separation of carbohydrates and polyols by a radially compressed HPLC silica column modified with TEPA. J. Chromatogr. 20: 45-53.

Lee, R. E. 1989. Insect cold-hardiness: to freeze or not to freeze. Bioscience 39: 308-313.

Loomis, S. H., S. C. Hand, and P. E. Fell. 1996. Metabolism of gemmules from the freshwater sponge Eunapius fragilis during diapause and post-diapause. Biol. Bull. 191: 385-392.

Mendicino, J., H. Abou-Issa, R. Medicus, and N. Kratowich. 1975. Fructose 1,6-diphosphate, phosphofructokinase, glycogen synthe- tase, phosphorylase, and proteinkinase from swine kidney. Methods Enzymol. 42: 375-392.

Peterson, G. L. 1977. A simplification of the protein assay method of Lowry et al. which is generally more applicable. Anal. Biochem. 83: 346-356.

Poirrier, M. A. 1969. Louisiana fresh-water sponges: taxonomy, ecology, and distribution. Ph.D. thesis. Louisiana State University. 173 pp. Baton Rouge, LA.

Rasmont, R. 1975. Freshwater sponges as a material for the study of cell differentiation. Curr. Top. Dev. Biol. 10: 141-159.

Simpson, T. L. 1984. The Cell Biology of Sponges. Springer-Verlag, New York. 622 pp.

Simpson, T. L., and G. A. Rodan. 1976. Role of cAMP in the release from dormancy of freshwater sponge gemmules. Dev. Biol. 49: 544547.

Storey, J. M., and K. B. Storey. 1983. Regulation of cryoprotectant metabolism in the overwintering gall fly larva, Eurosta solidaginis: temperature control of glycerol and sorbitol levels. J. Comp. Physiol. B. 149: 495-502.

Umbreit, W. W., R. H. Burris, and J. F. Stauffer. 1972. Manometric and Biochemical Techniques; a Manual Describing Methods Applicable to the Study of Tissue Metabolism. Burgess Publishing Co., Minneapolis. $387 \mathrm{pp}$.

Velle, W. 1975. Aldose reductase from seminal vesicle and placenta of ruminants. Methods Enzymol. 41(B): 165-170.

Wolff, John B. 1955. Sorbitol dehydrogenase from liver. Methods Enzymol. 1: 348-350. 